As this issue of JANZAM goes to press, the research productivity of New Zealand's universities has been systematically assessed for the first time. I hope that readers on the western side of the Tasman will bear with me if I reflect on this. A variant of the UK Research Assessment Exercise, New Zealand's Performance Based Rescarch Funding system (PBRF) has attracted a predictable range of responses, from quict satisfaction to determined denial, from competitive posing to predictions of collegiality destroyed. Whatever its merits and shortcomings, it offers management studies in our part of the world a lever that has long been wanting to develop our discipline to a state of equality with the long-established research-led subjects that dominate university life.

For nearly all of my 30 year career as a management academic (an anniversary I celebrate this week), I have worked in a university system that relied on the popularity of management studies to earn surpluses that were then used to shore up mature departments where enrolments were in decline. My colleagues and I have spent our careers carrying tcaching loads three or four times those in other parts of the university, very often to the detriment of our development as researchers. There have been some private costs to this regime, but they pale into insignificance next to the public loss from decades of management studies students proceeding through university, in their thousands, largely uninformed by bodics of research on management practice in our part of the world, and never appreciating that the knowledge that is most valuable is the knowledge you have to find for yourself.

So it came as no surprise to any of us that the PBRF exercise revealed a considerable gap between the research productivity of New Zealand's business schools and its more mature departments. The result will no doubt be used to affirm the prejudices of those for whom management studies is still an unwelcome upstart, but to me it offers also the ammunition we have needed for so long to shift universities' perception of us from cash cow to research priority.

This mid-year issue of JANZAM is a great exemplar of the kind of research-gencrated resources that should inform our lives as scholars and teachers of management. Kerr Inkson, New Zealand's lcading management academic and chair of the PBRF Business and Economics panel, offers the second of the JANZAM Leading Scholar Papers. Kerr is among the handful of most respected rescarchers in the world on careers, and a shining example himself of a research-led career. His paper is an authoritative review of a field in which he has been a pioneer, and offers a view of the organisation of the future that will remind all of his readers how stimulating a good mind can be.

This issue is also another of those happy accidents where complementary papers come together in the same volume. The focus this time is the vital theme of corporate governance with an important paper by Ingrid Bonn exploring the performance effects of board demographics in Australia's larger companies, and an innovative study by Gavin Nicholson, Malcolm Alexander and Geoffrey Kiel that analyses the social networks of board members in both Australia and the US. It is not appropriate to rob these authors of their punch lines, but here are some curios: women hold an average of just 4.8 percent of the board positions in these large Australian companies; and the US director with the biggest personal network is in direct or one-step-removed contact with no less than 874 other directors, almost 40 percent of all directors in the main network that governs America's top 250 firms.

Sandra Kiffin-Petersen's paper offers a carefully theorised model of the role that trust plays in team effectiveness. It is indeed paradoxical that trust has so far received little attention in this role, and 
Sandra's modelling leads to the important proposition that trust must influence the team's processes if it is to improve team effectiveness. Finally, Lisa Catherine Ehrich, Neil Cranston and Megan Kimber's paper develops a model of the pressures arising for public sector managers when confronted with an ethical dilemma, a model that is then road-tested, as it were, by a senior practitioner.

I am confident that many of these papers will be found in post-graduate seminars and paper citations for years to come. Solid research of the kind we are delighted to publish in this issue is an absolutely indispensable part of our craft as management academics, a function that JANZAM has been supporting now for 10 years. In the new world of PBRF, it is a part of our job that is no longer separable from the whole.

\section{Colin Campbell-Hunt}

\section{Editor}

